\title{
CONTINUING QUESTIONS IN CANADIAN \\ Political Finance LaW: THIRD PARTIES and SMall Political Parties
}

\author{
COLIN FEASBY*
}

\begin{abstract}
Canadian political finance law has struggled with the question of how to treat small political parties and third parties. The author contends that data gathered by Elections Canada concerning third party expenditures over the last four federal elections provides an opportunity to re-evaluate Harper v. Canada (A.G.), which was decided without a strong evidential foundation on the grounds of a reasonable apprehension of harm. The Ontario Court of Appeal's decision in Longley v. Canada (A.G.) upholding Canada Elections Act provisions that require political parties to meet vote thresholds to qualify for annual allowances, raises constitutional questions about the role of small political parties. The author questions whether a distinction should be made in law between large and small political parties and whether the fear that third parties may become political parties is a sufficient justification to limit the rights of small political parties.
\end{abstract}

\begin{abstract}
Le droit canadien sur les finances politiques a du mal avec le traitement des petits partis politiques et des tiers. L'auteur prétend que les données recueillies par Élections Canada au sujet des dépenses de tiers au cours des quatre derniers scrutins fédéraux permettent de réexaminer l'affaire Harper c. Canada (Procureur général), qui fut décidée sans solide valeur probante pour motif de crainte raisonnable de préjudice. La décision Longley c. Canada (Procureur général) de la Cour d'appel de l'Ontario, en maintenant les dispositions de la Loi électorale du Canada exigeant que les partis politiques obtiennent un minimum de votes pour avoir droit aux allocations annuelles, soulève des questions constitutionnelles au sujet du rôle des petits partis politiques. L'auteur se demande s'il faudrait faire la distinction dans la loi entre les petits et les gros partis politiques et il doute que la crainte que les tiers puissent devenir des partis politiques constitue une justification suffisante pour limiter les droits des petits partis politiques.
\end{abstract}

\section{TABLE OF CONTENTS}

I. INTRODUCTION . . . . . . . . . . . . . . . . . . . . . . . . . . . . 994

II. Third Party SPENDing Limits In CANADA . . . . . . . . . . . . . . . . 995

A. HARPER V. CANADA (A.G.) AND THE OBJECTIVES OF

THIRD PARTY SPENDING LiMits $\ldots \ldots \ldots \ldots \ldots \ldots . \ldots . \ldots 95$

B. Third Parties Under the New Legislative Regime . . . . . . . . 997

III. The UnCERTAin CONSTITUTIONAL PROTECTION

for SMALl Political Parties . . . . . . . . . . . . . . . . . . . . . . 1001

A. Political Party Funding AND Thresholds $\ldots \ldots \ldots \ldots \ldots . \ldots 1001$

B. Figueroa V. Canada (A.G.) . . . . . . . . . . . . . . . . . 1003

C. LONGLEY V. CANADA (A.G.) . . . . . . . . . . . . . . . . . . 1004

IV. Third PARTies AND SMALl Political Parties:

APPLES AND ORANGES? . . . . . . . . . . . . . . . . . . . . . . . . . . . . . . . 1009

A. Constitutional Justifications For Regulating

Third Parties and SMall Political Parties . . . . . . . . . . . 1009

B. ARE THIRD PARTIES A ReAl THREAT

to Political Party FinANCing? . . . . . . . . . . . . . . . . . . . . . . 1012

V. CONCLUSION ................................ 1016

Partner, Osler, Hoskin \& Harcourt LLP (Calgary, Alberta). The author thanks Chris Wu for his research assistance. This article was originally presented at the Political Finance Workshop, Institute of Advance Legal Studies, University of London in 2008. The author thanks the participants of the workshop for their comments. 


\section{INTRODUCTION}

Canada recently restructured its political finance regime. ${ }^{1}$ The traditional spending limits and expense reimbursement approach was supplemented with contribution limits and annual allowances for political parties. These changes raise a number of important constitutional questions. ${ }^{2}$ Perhaps not surprisingly, the first constitutional challenge to arise out of these changes - Longley - continued the dialogue about the participants that occupy the margins of the electoral process that has dominated Canada's jurisprudence of the democratic process. ${ }^{3}$ Longley weighed the constitutionality of the threshold of popular support required for a political party to qualify for an annual allowance. It is an important case because it limits the rule of equality between small and large political parties seemingly established by the Supreme Court of Canada in Figueroa. ${ }^{4}$ Longley also raises the question of the relationship between the regulatory and constitutional treatment of third parties (that is, individuals and interest groups) and small political parties.

Third party efforts to throw off the shackles of regulation in a series of cases beginning in the early 1980s and ending in 2004 were an abject failure. ${ }^{5}$ The right of third parties to participate in public discourse is now strictly limited during the period immediately before elections. Small political parties have fared better in the courts than third parties and have secured some constitutional protection, though not strict equality with major political parties. One of the factors that has prevented small political parties from achieving equal status with major political parties has been the close resemblance between third parties and small political parties. Indeed, the Attorney General argued in Longley that the possible misuse of the political party funding regime by third parties was a good reason to prevent political parties with limited public support from obtaining financial allowances. The Attorney General's position enjoyed the support of a number of eminent political scientists and legal scholars. The Ontario Court of Appeal's decision does not clearly endorse or disavow the Attorney General's position. However, the objective of public funding thresholds identified by the Court, "misuse of funds," can be interpreted broadly to include the distribution of funds to small political parties that resemble third parties.

1 The Canadian political finance regime is largely embodied in the Canada Elections Act, S.C. 2000, c. 9 [CEA]. The recent changes are found in An Act to amend the Canada Elections Act and the Income Tax Act (political financing), S.C. 2003, c. 19; see also Federal Accountibility Act, S.C. 2006, c. 9. For a good analysis of these changes, see K.D. Ewing, The Cost of Democracy: Party Funding in Modern British Politics (Oxford: Hart, 2007) at 197-223.

2 Colin Feasby, “Constitutional Questions About Canada’s New Political Finance Regime” (2007) 45 Osgoode Hall L.J. 513 [Feasby, “Constitutional Questions”].

3 Longley v. Canada (A.G.) (2006), 82 O.R. (3d) 481 (Sup. Ct. J.) [Longley (Sup. Ct. J.)], rev’d 2007 ONCA 852, 88 O.R. (3d) 408 [Longley (C.A.)] leave to appeal to S.C.C. refused, 32459 (24 April 2008) [Longley (S.C.C.)].

$4 \quad$ Figueroa v. Canada (A.G.), 2003 SCC 37, [2003] 1 S.C.R. 912 [Figueroa]. See Heather MacIvor, "Judicial Review and Electoral Democracy: The Contested Status of Political Parties under the Charter" (2002) 21 Windsor Y.B. Access Just. 479; Heather MacIvor, “The Charter of Rights and Party Politics: The Impact of the Supreme Court Ruling in Figueroa v. Canada (Attorney General)” (2004) 10:4 Choices, online: Institute for Research on Public Policy <http://www.irpp.org>.

$5 \quad$ National Citizens' Coalition Inc. v. Canada (A.G.) (1984), 11 D.L.R. (4th) 481 (Alta. Q.B.); Somerville v. Canada (A.G.) (1996), 184 A.R. 241 (C.A.); Libman v. Quebec (A.G.), [1997] 3 S.C.R. 569 [Libman]; Pacific Press v. British Columbia (A.G.), 2000 BCSC 248, [2000] 5 W.W.R. 219; Harper v. Canada (A.G.), 2004 SCC 33, [2004] 1 S.C.R. 827 [Harper (S.C.C.)]. 
The issues discussed in this article engage ss. 2(b) and 3 of the Canadian Charter of Rights and Freedoms. ${ }^{6}$ Section 2(b) guarantees freedom of expression. Section 3 guarantees political rights including the right to vote and the right to be a candidate for election. For the most part, third party spending restrictions are considered under the rubric of s. 2(b) and small political party funding issues are considered in the context of s. 3. If a legislative measure is found to violate either s. 2(b) or s. 3, the state is required to justify the infringement of constitutional rights under s. 1 . A s. 1 analysis involves a determination of whether the legislative objective is pressing and substantial, and an evaluation of proportionality which, in turn, has three parts: rational connection, minimal impairment, and a comparison of the deleterious and salutary effects of the impugned legislation. Given the common context, most decisions concerning election issues blur the distinction between $\mathrm{s}$. 2(b) and s. 3 once a violation of a constitutional right is found.

Part II of this article reviews the reasons for regulating third parties and the Canadian experience of third party regulation. The reasons for regulating third parties are not new, but they are of particular interest for the purpose of comparison with the reasons offered for public funding thresholds for political parties. The federal third party disclosure and spending limit regime has now been in place for four federal general elections and there is enough data to start to appreciate who the active third parties are and the levels of spending under the regime. In turn, this facilitates an evaluation of the justifications offered to courts for regulating third parties. Part III of this article concerns small political parties. The analysis begins with a look back at Figueroa, which undermined the longstanding practice of drawing distinctions between small and large political parties by outlining a potentially far-reaching equality principle. The latter section of the third part of the article explains and criticizes the Ontario Court of Appeal's decision in Longley, which appears to be inconsistent with Figueroa and may signal a return to a two tiered approach to the regulation of political parties. Part IV looks more closely at some of the issues raised directly and indirectly by Longley. In particular, it is considered whether the resemblance between third parties and small political parties is a good reason for denying public funding to small political parties.

\section{Third PARTy SPENDing Limits In CANAdA}

\section{A. HARPER V. CANADA (A.G.) AND THE OBJECTIVES OF THIRD PARTY SPENDING LIMITS}

Much has been written about Harper, so only the basic facts and principles will be repeated here. ${ }^{7}$ The case was brought by Mr. Harper, Canada’s current Prime Minister, who was then the leader of a conservative advocacy group called the National Citizens' Coalition. Harper challenged amendments to the $C E A,{ }^{8}$ adopted in 2000, that limited the ability of third parties to spend money during elections and required third parties to disclose financial not to decide elections cases on s. 15(1) grounds unless s. 3 does not apply: see Corbiere v. Canada (Minister of Indian and Northern Affairs), [1999] 2 S.C.R. 203.

$7 \quad$ For a more detailed discussion of Harper, see Andrew Geddis, "Liberté, Egalité, Argent: Third Party Election Spending and the Charter" (2004) 42 Alta. L. Rev. 429; Colin Feasby, "Freedom of Expression and the Law of the Democratic Process” (2005) 29 Sup. Ct. L. Rev. (2d) 237. Supra note 1. 
information to Elections Canada. Harper succeeded at trial and in the Alberta Court of Appeal. ${ }^{9}$

The key question for the Supreme Court of Canada in Harper was the characterization of the objectives of third party spending limits. For the purposes of this article, it is important to understand the objectives found by the Supreme Court of Canada, as that permits a critical analysis in light of the third party data collected in the last four federal general elections. An understanding of the objectives is also essential for the purpose of evaluating the reasons offered for treating minor political parties differently from third parties, and differently from major political parties.

In Harper the Supreme Court identified three pressing and substantial objectives of third party spending limits. These objectives were: (1) "to promote equality in the political discourse"; (2) "to protect the integrity of the financing regime applicable to candidates and [political] parties"; and (3) "to maintain confidence in the electoral process." 10 Other objectives, and variations on the Supreme Court's objectives, have been offered by critics; however, discussion here will be limited to the objectives identified by the Supreme Court. ${ }^{11}$

The promotion of equality in political discourse is the classic egalitarian justification for political finance controls. ${ }^{12}$ The premise is that those with greater financial resources should not be allowed to translate that advantage into an advantage in the electoral arena. Citizens are equals and, subject to their innate talents, should have an equal opportunity to succeed in the electoral arena irrespective of their social or economic class. ${ }^{13}$ Unconstrained political spending threatens to create a situation where the wealthy have a disproportionate ability to influence policy outcomes. ${ }^{14}$ In the long term, the argument continues, this could undermine the political system and stifle social mobility.

There are two main criticisms of the egalitarian position. The first, which has been dismissed by the Supreme Court, is that freedom of expression is more important than equal opportunity for participation in political discourse.$^{15}$ The second criticism of the egalitarian position is that there is no real evidence that third party money influences electoral outcomes. Indeed, one of the points put forth by the Alberta Court of Queen's Bench in Harper was that the study that was relied upon by Parliament in enacting the third party spending limits was discredited. ${ }^{16}$ The Supreme Court dispensed with this concern explaining that "logic and reason assisted by some social science evidence [was] sufficient” to establish a pressing and substantial objective. ${ }^{17}$ Furthermore, the third party spending limits were found to be rationally connected to the objective because "[a]n upper limit on the amount that third

Harper v. Canada (A.G.), 2001 ABQB 558, 295 A.R. 1 [Harper (Q.B.)], rev'd in part 2002 ABCA 301, 320 A.R. 1 [Harper (C.A.)].

Supra note 5 at paras. 101-103.

See supra note 7.

For a discussion of the egalitarian position, see Colin Feasby, "Issue Advocacy and Third Parties in the United Kingdom and Canada" (2003) 48 McGill L.J. 11 at 16-21.

John Rawls, "The Basic Liberties and Their Priority" in Stephen Darwall, ed., Equal Freedom: Selected Tanner Lectures on Human Values (Ann Arbor: University of Michigan Press, 1995) 105 at 175.

John Rawls, A Theory of Justice (Oxford: Oxford University Press, 1973) at 225.

See Libman, supra note 5.

Harper (Q.B.), supra note 9 at paras. 75, 266-73.

Harper (S.C.C.), supra note 5 at para. 79. 
parties can dedicate to political advertising curtails their ability to dominate the electoral debate."18

The second objective identified by the Supreme Court, the protection of the integrity of the financing regime applicable to candidates and political parties, is concerned with competitive balance and anti-avoidance. In a system where political party and candidate expenditures are limited, political parties and candidates supported by third parties, intentionally or by happenstance, have an unfair advantage. ${ }^{19}$ Similarly, those opposed by third parties have an unfair disadvantage. Limiting third party expenditures reduces the likelihood that political parties and candidates will seek to channel funds to like-minded third parties for parallel or allied advertising campaigns. Limits on third party spending also reduce the pressure on political parties and candidates to exceed spending limits in an effort to respond to attacks by third parties.

The protection of the integrity of the financing regime applicable to candidates and political parties is a more compelling objective than the egalitarian argument in the context of third party spending limits. More accurately, the integrity argument is complementary to the egalitarian justification for political finance regulation generally. Leaving aside the issue of whether there is evidence of the impact of third party spending, it is clear that the most efficient use of money by someone who wishes to affect an electoral outcome or gain influence or access is to contribute money directly to a candidate or political party. Contributing to a third party is an indirect and less efficient way to deploy money in the political arena if affecting electoral outcomes or gaining influence or access is the objective.

The third purpose of third party spending limits identified by the Supreme Court is to maintain confidence of the public in the electoral process. Third party spending limits foster confidence by negating the perception that political parties can "circumvent their spending limits through the creation of special interest groups." ${ }^{20}$ The Court also observed that third party limits address the perception that the wealthy can dominate the political process. ${ }^{21}$ In other words, the regulation accords with the public's conception of fairness. This objective adds little to the first two objectives identified by the Supreme Court.

\section{B. Third Parties Under the NeW Legislative Regime}

The current third party spending limits were introduced as part of the new Canada Elections Act in 2000. Third parties are allowed to spend up to \$3,000 per local district and up to $\$ 150,000$ in aggregate..$^{22}$ Like candidate and political party spending limits, third party spending limits are indexed to inflation. The limits for the 2008 federal general election were $\$ 3,666$ per electoral district and $\$ 183,300$ in aggregate. ${ }^{23}$

Ibid. at para. 107.

Ibid. at para. 108.

Ibid. at para. 109 [emphasis in original].

Ibid.

CEA, supra note 1 , s. 350 .

Elections Canada, "Limit on Election Advertising Expenses Incurred by Third Parties," online: Elections Canada <http://www.elections.ca/content.asp?section=fin\&document=limit_tp\&dir=lim\& lang=e\&textonly $=$ false $>$. 
Since the adoption of third party spending limits, there have been four federal general elections: 2000, 2004, 2006, and 2008. The third party returns from each of these elections provide some data that gives a basis to evaluate, however tenuously, the assumptions that motivated the controls. The data taken from the third party returns is imperfect and any conclusions that may be drawn from the analysis of the data are subject to the limitations of the source data. One concern is that, for the three most recent elections, some registered third parties have failed to file returns with Elections Canada. The failure to file a return may reflect either that no expenditures were made, or that after making expenditures the third party failed to comply with its statutory obligations. Another concern is that it is impossible to know if unreported third party spending activities are occurring. This latter concern is addressed by the apparent activity of the Commissioner of Elections as indicated by the existence of a number of "compliance agreements," which are essentially admissions of guilt relating to non-compliance with third party regulations. ${ }^{24}$ Some comfort may also be taken from the absence of any obvious unreported third party campaigns and the lack of public complaints from candidates and political parties.

One of the great concerns that motivated the regulation of third parties was that elections would be influenced by wealthy individuals and corporations. There has, however, been a dearth of corporations registered as third parties in the last four federal general elections. This is true even of the 2006 and 2008 elections, for which the ban on corporate contributions was in force. Similarly, neither the third parties nor those contributors to third parties whose identities are disclosed appear to be amongst Canada's richest citizens. Instead, third parties appear to be four types of individuals or organizations: (1) labour unions and trade/professional associations; (2) student associations; (3) activist groups (for example, environmental); and (4) groups promoting or opposing local candidates.

Table 1, below, shows that total third party expenditures increased from $\$ 573,854.20$ in 2000 to $\$ 1,430,579.14$ in 2008. Similarly, the number of registered third parties increased from 50 to 64 over the same time period. There is a trend (see Figures 1 and 2, below) to increased numbers of third parties and an increase in total third party expenditures. At first glance, this trend might appear to be consistent with the concern that motivated the adoption of third party spending limits: that third parties might distort the competitive balance at the local or national level. To be properly understood, however, this trend needs to be viewed in the context of the expenditures and expenditure limits of candidates and political parties. The third party local spending limit of \$3,666 for the 2008 federal general election compares to local candidate spending limits for the same election that ranged from approximately $\$ 70,000$ to approximately $\$ 100,000$, depending on electoral district population. ${ }^{25}$ At these levels, it is difficult to imagine a single third party altering the competitive balance between candidates, even if it spent the maximum allowed under the limits. For an election to be

24 The Commissioner of Elections is empowered to enter into “compliance agreements” as an alternative to prosecuting non-compliance. Compliance agreements usually involve registering and filing with respect to past expenditures, and a promise to comply in the future. Sometimes compliance agreements will also involve a voluntary fine or contribution to a non-political charitable organization. All compliance agreements are available in the Canada Gazette and online: Elections Canada <http:// www.elections.ca>.

25 Elections Canada, “40th General Election: Final Candidates Election Expenses Limits,” online: Elections Canada <http://www.elections.ca/content.asp?section+pas\&document=index\&dir=40ge/lim can\&lang $=$ e\&textonly $=$ false $>$. 
affected it would require that a number of third parties be aligned with one candidate. ${ }^{26}$ The situation closest to this scenario occurred in the 2000 federal general election, where three third parties advocated the re-election of Anne McLellan, who was then a Liberal cabinet minister, and a further five third parties with undeclared purposes were from the Edmonton area. $^{27}$

TABLE 1

THIRD PARTY EXPENDITURES IN THE 2000, 2004, 2006, AND 2008 GENERAL ELECTIONS ${ }^{28}$

\begin{tabular}{|c|c|c|c|c|}
\hline & \multicolumn{4}{|c|}{ Number of Registered Third Parties } \\
\hline Expenditure Levels & $2000^{*}$ & 2004 & 2006 & 2008 \\
\hline No return & 0 & 4 & 7 & 4 \\
\hline$\$ 0.00$ & 6 & 12 & 7 & 3 \\
\hline$\$ 0.01-\$ 4,999.99$ & 30 & 31 & 44 & 32 \\
\hline$\$ 5,000.00-\$ 9,999.99$ & 8 & 4 & 2 & 4 \\
\hline$\$ 10,000.00-\$ 24,999.99$ & 2 & 4 & 5 & 7 \\
\hline$\$ 25,000.00-\$ 49,999.99$ & 1 & 3 & 8 & 5 \\
\hline$\$ 50,000.00-\$ 99,999.99$ & 1 & 4 & 5 & 4 \\
\hline$\$ 100,000.00$-and over & 2 & 1 & 2 & 5 \\
\hline Total Number & 50 & 63 & 80 & 64 \\
\hline Total Expenditures & $\$ 573,854.20$ & $\$ 720,227.93$ & $\$ 1,067,680.75$ & $\$ 1,430,579.14$ \\
\hline Average Expenditure & $\$ 11,477.08$ & $\$ 12,207.25$ & $\$ 14,625.76$ & $\$ 23,842.99$ \\
\hline
\end{tabular}

* The data for 2000 is compromised by the fact that during mid-campaigning an injunction was issued by the Alberta Court of Queen's Bench suspending the rules applicable to third parties and then restated by the Supreme Court of Canada.

- Does not include third parties with no return filed.

26 The returns filed by third parties following the 2008 Federal Election do not provide any information that allows an assessment of co-operative action with other third parties. Furthermore, only a small minority of third party returns identify expenditures as being in relation to a specific electoral district. While this may be because third parties are conducting a more general campaign at the regional or national level, it may also be indicative of poor reporting and enforcement. The frailties of the third party return data precludes a more detailed analysis of third party impacts at the electoral district level.

The names of the three third parties were: Edmonton Supporters of Anne McLellan, Edmontonians for Anne McLellan, and Coalition for Anne McLellan. A less dramatic example is found in the 2006 election where there were two groups supporting Liberal cabinet minister Tony Valeri: Citizens for Valeri and Canadian Croatians for Valeri.

28 Elections Canada, "Other Participants (Third Parties) — Political Financing and Other Information," online: Elections Canada <http://www.elections.ca/content.asp?section=fin\&dir=thi\&document=index \&lang=e\&textonly=false $>$ [Elections Canada, "Other Participants"]. 
Figure 1 - THIRD PARTY REgistration ${ }^{29}$

FIgURE 2 - TOTAL THIRD PARTY EXPENDITURES ${ }^{30}$

29 Elections Canada, "Registered Third Parties," online: Elections Canada <http://www.elections.ca/ content.asp?section=pol\&document=index\&dir+thi/tie\&lang=e\&textonly=false $>$.

30 Supra note 28. 
Total third party expenditures, though increasing, pale in comparison to political party expenditures. For example, the Conservative Party reported expenditures in the 2008 federal general election, not including local candidate expenditures, of \$19,418,579.89. Liberal Party expenditures in the 2004 federal general election, including local candidate expenditures, were $\$ 34,330,792.00 .^{31}$ Expenditures of all political parties in 2008 totalled \$58,525,953.61 (not including local candidate expenditures).$^{32}$ Given that third party expenditures in the four elections were divided up amongst 50 to 80 entities with disparate agendas, it is hard to see how the competitive balance could have been affected at the national level.

Perhaps the most interesting finding revealed by the third party returns is that none of the third parties spent the maximum amount allowed. Indeed, very few third parties (eight over four elections) spent $\$ 100,000.00$. This suggests that either the third party spending limit is so chilling that potential third parties shun involvement in elections, or that there is little demand for the big money third party campaign as feared by Parliament. The large number of third parties registered suggest that the controls are not chilling; rather, it suggests that the third party threat is overrated.

\section{The Uncertain Constitutional Protection for SMall Political Parties}

\section{A. Political Party Funding and Thresholds}

There are a number of forms of public funding for political parties: tax receipts for contributions; ${ }^{33}$ free and discounted broadcasting time; ${ }^{34}$ reimbursement of campaign expenditures; ${ }^{35}$ and quarterly allowances. ${ }^{36}$ The last two forms of funding are subject to thresholds of electoral support that must be satisfied prior to a political party being eligible to receive funds. A political party must obtain 2 percent of the national popular vote or 5 percent of the vote in the electoral districts contested by the political party to qualify for reimbursement of election expenses and an annual allowance. ${ }^{37}$ The reimbursement is equal to 50 percent of the political party's election expenditures. At the time that the funding thresholds were introduced they only applied to the reimbursement of election expenditures, as there were not yet any allowances for political parties. The funding thresholds were applied to allowances when they were introduced in 2003. The annual allowances are equal to $\$ 1.75$ per vote in the previous federal general election, multiplied by an inflation factor, with payments made quarterly. ${ }^{38}$

Liberal Party expenditures in the 2008 federal general election, including local candidate expenditures, were \$27,818,495.38: see PriceWaterhouseCoopers, “Auditors’ Report to Federal Liberal Agency of Canada, Chief Agent for the Liberal Party of Canada," online: Elections Canada <http://www.elections ca/pol/exp2008/lib.pdf>; Elections Canada, "Financial Reports: Canadidate’s Electoral Campaign Return," online: Elections Canada <http://www.elections.ca/scripts/webpep/fin/2/select_search_option. aspx $>$. The decline from 2004 may reflect the Liberal Party's declining financial condition over the period 2004-2008.

Elections Canada, "Political Parties - Political Financing and Other Information," online: Elections Canada <http://www.elections.ca/content.asp?section=fin\&dir=pol\&document=index\&lang=e\&text only=false $>$.

Income Tax Act, R.S.C. 1985 (5th Supp.), c. 1, ss. 127(3)-(4.1).

CEA, supra note 1, ss. 332-48.

Ibid., s. 435.

Ibid., s. 435.01.

Ibid., ss. 435 (reimbursement of election expenses), 435.01 (quarterly allowances).

Ibid., s. 435. 
Parliament's decision not to extend annual allowances to small parties was not a financial issue. Annual allowances are determined by the number of votes received in the most recent federal general election. The maximum cost of the annual allowance program is fixed by the number of votes. If all votes were cast for candidates of the major parties then there could be no objection to the cost of the program. Indeed, the increased cost of the annual allowances is trivial when compared to funding given to large political parties, and to government expenditures in general. ${ }^{39}$ Indeed, as will be discussed later in this article, the Attorney General did not argue in Longley that it was too expensive to extend the annual allowance program to small political parties.

The funding thresholds were introduced by way of a private member's bill to amend the CEA in $1996 .{ }^{40}$ The apparent motivation for the introduction of thresholds was that the funding system for political parties could be misused. During the 1993 federal general election, the Natural Law Party fielded candidates in over two thirds of the electoral districts nationally and received approximately 85,000 votes ( 0.6 percent of the national vote). ${ }^{41}$ The Natural Law Party is remembered fondly by many as the party whose most famous candidate was celebrity magician Doug Henning, and whose principal campaign plank was the use of widespread meditation or "yogic flying," as it was called, to bring peace and harmony to the world. It has been suggested that the Natural Law Party's real purpose was not to elect candidates to the House of Commons, but "to advertise its contemplative lifestyle, promote its fee based meditation courses and enhance its commercial aims.”42 Indeed, instead of relying on volunteer candidates, it is said to have hired some of its candidates to run for election. ${ }^{43}$ The Natural Law Party received $\$ 717,000$ to reimburse it for expenditures during the 1993 election. $^{44}$

The political party funding thresholds were adopted at a time when there was good reason to believe that funding thresholds did not raise constitutional questions. The political party funding thresholds are paralleled by thresholds that apply to the reimbursement of candidate election expenses. Candidates are required to obtain 10 percent of the vote before being eligible for reimbursement of election expenses. ${ }^{45}$ In 1994, the Quebec Court of Appeal considered the constitutionality of the candidate expense reimbursement threshold in Barrette. ${ }^{46}$ The reimbursement threshold considered in Barrette was 15 percent of the popular vote in an electoral district. The Court held that the thresholds did not violate ss. 3 or 15 of the Charter and, accordingly, did not require any rights violation to be justified. This conclusion was seemingly contradicted by Figueroa, which followed in 2003 and is

The cost of extending the annual allowance program to all unfunded parties for the period 1 April 2008 to 31 March 2009 would have been $\$ 125,585.74$ (64,304 votes * \$1.75* inflation factor of $1.116=$ $\$ 137,514)$. For voting data, see Elections Canada, “Official Voting Results, Fortieth General Election 2008, Table 8," online: Elections Canada <http://www.elections.ca/scripts/OVR2008/default.html>. For the inflation factor, see Elections Canada, "Quarterly Allowances to the Registered Political Parties (2009)," online: Elections Canada <http://www.elections.ca/content.asp?section=pol\&document=qua 2009\&dir=pol/qua\&lang $=\mathrm{e} \&$ textonly $=$ false $>$.

40 Bill C-243, An Act to amend the Canada Elections Act (Reimbursement of Election Expenses), 2nd Sess. 35th Parl., 1996 (assented to 22 October 1996), S.C. 1996, c. 26.

Longley (C.A.), supra note 3 at para. 13.

Ibid.

Ibid.

Ibid.

CEA, supra note 1, s. 464.

Barrette c. Canada (Procureur générale) (1994), 113 D.L.R. (4th) 623 [Barrette]. 
discussed in the next section of this article. ${ }^{47}$ Interestingly, however, there have been no constitutional challenges to the candidate expense reimbursement thresholds since Figueroa.

\section{B. Figueroa V. CANADA (A.G.)}

Figueroa was brought by the leader of the Canadian Communist Party (CCP). Mr. Figueroa challenged the requirement that a political party must nominate candidates in 50 electoral districts to be "registered." Registered political parties were entitled to special privileges including: the right to issue tax receipts to donors; ballot identification; and the ability to transfer unused campaign funds from candidates to the political party ${ }^{48}$ The effect of the 50-candidate threshold was to unfairly disadvantage small political parties such as the CCP. The argument advanced by Figueroa was essentially that $\mathrm{s} .3$ of the Charter requires that candidates be treated equally whether they are associated with a large political party or a small political party. Differential treatment of large and small political parties, then, prejudiced the rights of citizens as candidates to participate fully and equally in the democratic process.

The Supreme Court agreed with Figueroa's position. The Court recognized not only the rights of small political parties, but the value of small political parties to the democratic process. Justice Iacobucci wrote that "all political parties, whether large or small, are capable of acting as a vehicle for the participation of individual citizens in the public discourse that animates the determination of social policy." ${ }^{\text {"9 }}$ The Court went on to explain that s. 3 of the Charter does not prohibit differential treatment of individuals; rather, it prohibits differential treatment that has "an adverse impact upon the applicant's right to play a meaningful role in the electoral process." ${ }^{50}$ Put another way, the Court held that "legislation that exacerbates a pre-existing disparity in the capacity of the various political parties to communicate their positions to the general public is inconsistent with s. $3 .{ }^{, 51}$

The Attorney General offered three objectives to explain why the 50-candidate requirement was justified under s. 1 of the Charter. For the purposes of this article, the most relevant justification is that of "protecting the integrity of the electoral financing regime." 52 The Court readily accepted that protecting integrity by preventing the misuse of public funding was an important objective. Misuse of funds in this sense included distribution of funds to third parties that pretended to be political parties. However, the Court was very skeptical of the utility of the 50-candidate threshold in controlling the misuse of public funds. Specifically, the Court noted that legitimate political parties "with a genuine intention of participating in the electoral process" sometimes did not meet the 50-candidate threshold. ${ }^{53}$ In other words, the threshold was overbroad. Moreover, the Court found that the Attorney

For a discussion of Barrette and the implications of Figueroa, see Colin Feasby, "The Supreme Court of Canada's Political Theory and the Constitutionality of the Political Finance Regime” in K.D. Ewing \& Samuel Issacharoff, eds., Party Funding and Campaign Financing in International Perspective (Portland: Hart, 2006) 243.

Figueroa, supra note 4 at paras. 4-8.

Ibid. at para. 41.

Ibid. at para. 51.

Ibid. at para. 54 .

Ibid. at para. 71 .

Ibid. at para. 75 . 
General had failed to show that the threshold prevents third parties from gaining access to public funds. The Court went on to observe that

\begin{abstract}
there are a substantial number of obligations that a registered party must comply with, such as submitting audited financial statements, audited financial transactions returns and audited election expenses returns. Absent evidence indicating that these requirements are not sufficient to prevent third parties from seeking registered party status for the sole purpose of abusing the tax credit scheme, there is no basis for concluding that the 50-candidate threshold actually advances the objective of preventing the misuse of the electoral financing regime. ${ }^{54}$
\end{abstract}

The Court also noted, in the context of considering the misuse of funds rationale, that the 50 -candidate limit did not minimally impair s. 3 rights. The Court concluded that the "logical inference is that precisely the same result could be achieved through strict spending rules and the use of auditors." 55

At the conclusion of its analysis, the majority of the Court concluded not only that the 50candidate threshold was unconstitutional, but that no threshold could be found to be constitutional based on the case advanced by the Attorney General. ${ }^{56}$ Figueroa, however, was not an unqualified victory for small political parties. The Court conceded that when considering other aspects of the political finance regime relating to small political parties, it might be necessary to consider other factors. ${ }^{57}$ Moreover, the Court stated that its reasons in Figueroa did not "stand for the proposition that an infringement of s. 3 arising from the differential treatment of political parties could never be justified." 58

\title{
C. LONGLEY V. CANADA (A.G.)
}

\section{The Superior COURT DeCISION}

Mr. Longley, the named plaintiff, is the leader of the Marijuana Party of Canada. ${ }^{59} \mathrm{He}$ and his political party brought the case jointly with the Canadian Action Party, ${ }^{60}$ the CCP ${ }^{61}$ the Marxist-Leninist Party, ${ }^{62}$ the Progressive Canadian Party, ${ }^{63}$ the Green Party of Canada, ${ }^{64}$ the Christian Heritage Party, ${ }^{65}$ and their respective leaders or chief agents. This collection of parties includes many of the Canadian political parties who have participated in recent

Ibid. at para. 76 .

Ibid. at para. 78 .

Ibid. at para. 92.

Ibid. at para. 91 .

Ibid.

The Marijuana Party’s policies can be found online: Marijuana Party of Canada <http://www.marijuana party.org $>$.

60 The Canadian Action Party's policies can be found online: The Canadian Action Party <http://www. canadianactionparty.ca>.

61 The Communist Party of Canada’s policies can be found online: Communist Party of Canada <http:// www.communist-party.ca>.

62 The Marxist-Leninist Party’s policies can be found online: Marxist-Leninist Party <http://www.cpcml. ca>.

63 The Progressive Canadian Party's policies can be found online: Progressive Canadian Party $<$ http://www.progressivecanadian.ca>.

64 The Green Party of Canada’s policies can be found online: Green Party of Canada <http://www.green party.ca>.

65 The Christian Heritage Party's policies can be found online: Christian Heritage Party of Canada <http://www.chp.ca>. 
elections and have failed to meet the thresholds for public funding. The Green Party is the only plaintiff that has succeeded in obtaining enough votes to qualify for an allowance. ${ }^{66}$ The parties range in scope from the single issue Marijuana Party to parties that offer more comprehensive platforms. The plaintiff political parties also represent a diversity of ideological perspectives. Some of the plaintiff political parties are recent creations, while others, such as the CCP, date back almost a century. The only common feature amongst these political parties is that they are small.

The plaintiff political parties in Longley relied on the affidavits of individuals from each of the plaintiff political parties and an affidavit from Lawrence Leduc, a political science professor from the University of Toronto. Professor Leduc's affidavit makes several important points: funding thresholds create a systemic bias in favour of major political parties; funding thresholds undermine the inherent fairness in funding based on popular vote share; and the funding thresholds may have unintended consequences. He also noted that the financial and regulatory burden of being a registered political party "guards against the possibility that removing the voter thresholds would allow an organization that is not seriously competing in elections to use electoral funding as a way to make a profit.”67

The Attorney General responded with affidavits from a small army of experts. ${ }^{68}$ The most important affidavits were those of Professors Lisa Young and Peter Aucoin, who spoke to the reasons for public funding thresholds, and that of Professor Keith Ewing, who spoke to the use of funding thresholds in political finance regimes around the world. According to Professors Young and Aucoin, the rationale for funding thresholds was to prevent the misuse of public funds. Misuse, according to Professors Aucoin and Young, appears to range from commercial exploitation of public funding, to use by frivolous or satirical political parties, to the funding of interest groups that otherwise would fall into the category of third parties. ${ }^{69}$ Professor Ewing concurred with the last of these views and added that there have been "concerns in the past about the danger of giving public money to extremist parties on the right which foster racist and other anti-democratic sentiments."70

The application judge sidestepped much of the evidence filed in the case and held that the issues to be decided in Longley were the same in principle as in Figueroa and could not be distinguished. ${ }^{71}$ The funding threshold was accordingly found to be a violation of the right to vote as found in s. 3 of the Charter. ${ }^{72}$ While the application judge's reasoning is sparse because of his finding that Figueroa dictated the outcome of the case, the essence of his

$66 \quad$ Longley (Sup. Ct. J.), supra note 3 at para. 6.

67 Ibid., (Evidence, Affidavit of Lawrence Leduc at para. 10 [Leduc Affidavit]). See " $2 \%$ challenge court application and affidavits,” online: Marijuana Party of Canada <http://www.marijuanaparty.ca/article. php3id_article=266>.

68 Peter Aucoin, Dalhousie University; Herman Bakvis, University of British Columbia; Keith Ewing, King's College, University of London; Louis Massicotte, University of Montreal; Lisa Young, University of Calgary.

$69 \quad$ Longley (Sup. Ct. J.), supra note 3 (Evidence, Affidavit of Lisa Young [Young Affidavit]); (Evidence, Affidavit of Peter Aucoin [Aucoin Affidavit]). See "Crown's Affidavits in 2\% challenge court case," online: Marijuana Party of Canada <http://www.marijuanaparty.ca/article.php3?id_article=33. [“Crown's Affidavits”].

70 Ibid. (Evidence, Affidavit of Keith David Ewing at para. 50 [Ewing Affidavit]). See “Crown's Affidavits," ibid.

Longley (Sup. Ct. J.), supra note 3 at para. 18.

The funding thresholds were also found to violate s. 15(1) of the Charter: see ibid. at paras. 30-34. 
conclusion can be divined. Figueroa held that s. 3 of the Charter guarantees citizens a right to meaningfully participate in the electoral process. The application judge determined that money is required for citizens, or groups of citizens organized as a political party, to meaningfully participate in the electoral process. As such, the denial of funding to small political parties, no matter how meagre the sums, limits the right of citizens or groups of citizens to meaningfully participate in the electoral process. ${ }^{73}$

Most of the analytical heavy lifting in the Charter analysis is done in the context of s. 1, where the state is required to justify infringements of Charter rights. Here too, the application judge held that Figueroa was a controlling precedent. ${ }^{74}$ The arguments presented by the Attorney General were, in essence, the same as those presented in Figueroa. The application judge also commented on what he considered to be a lack of evidence supporting the need for funding thresholds. ${ }^{75}$

The application judge went on to make several pointed criticisms of the funding thresholds. First, he concluded that the only benefit of the thresholds was the benefit conferred on the political parties that qualified for public funding. ${ }^{76}$ Put another way, the major political parties benefited from the threshold, but it was not proven that the threshold produced any real benefits for the electoral process as a whole. Second, the threshold was not required for any practical purpose, as the amount of funding is determined by the number of votes. ${ }^{77}$ Third, the funding thresholds create perverse incentives for small political parties. Rather than encouraging small political parties to run candidates in every electoral district, the structure of the thresholds encourages small political parties to run in only those electoral districts where they have the best chance of obtaining 5 percent of the vote. The funding thresholds thereby diminish the electoral choices of citizens and erect a structural impediment for small political parties to become major political parties. ${ }^{78}$ Lastly, he noted that providing funding based on the numbers of votes encourages citizens to vote. The tie between votes and public funds means that there is good reason for the supporters of a political party to vote, even in electoral districts where the political party's candidate is unlikely to win. Such an incentive should promote higher voter turnout. However, as the application judge concluded, "[t]he quality and vigour of Canadian democracy suffers because such a threshold effectively discourage[s] individuals who do not support one of the larger parties from participating in the electoral process."79

The Attorney General's main argument, or at least the one fixed upon by the Court of Appeal, was that funding thresholds were required to maintain the integrity of, and public confidence in, the political finance regime. This is one of the three justifications endorsed by the Supreme Court of Canada in Harper in the context of third party spending limits, although the Court found there to be insufficient evidence of harm. ${ }^{80}$ In the specific context of the funding thresholds, the Attorney General contended that public confidence in the

Ibid. at para. 16 .

Ibid. at para. 19.

Ibid. at paras. 20-22.

Ibid. at para. 23.

Ibid.

Ibid. at para. 24.

Ibid. at para. 25.

Harper (S.C.C.), supra note 5 at para. 39. 
political finance regime would be undermined if frivolous groups or commercial entities were to receive funding intended for serious participants in the electoral process. The application judge, however, found this submission unpersuasive:

In my view, [the argument that thresholds are required to maintain integrity and public confidence] is also without merit. I consider that the existence of the threshold diminishes public confidence in the electoral process and encourages a public perception that the threshold exists only to benefit the major political parties who alternate, from time to time, in forming the government and are in a position to maintain it. ${ }^{81}$

As the application judge's comments show, the question of public confidence cuts both ways. Is public confidence more affected by the receipt of funds by frivolous groups and commercial entities, or the denial of funds to small, but sincere, participants in the electoral process?

Two other arguments were available to the application judge, but were not deployed. First, the public funding formula is such that harm in terms of the misuse of funds will always be small because most voters will vote for genuine political parties, whether large or small. Moreover, it is a dubious proposition that public confidence can be undermined by funding distributed according to a result dictated by the votes of citizens. Second, the trial judge did not expressly consider Parliament's conflict of interest in limiting the availability of public funding to small political parties. ${ }^{82}$ The natural interest of the major political parties in limiting the electoral opportunities of small political parties could have been used by the application judge to justify his refusal to give deference to Parliament under the proportionality aspects of the s. 1 analysis.

\section{COURT OF APPEAL DECISION}

Justice Blair, writing for the Ontario Court of Appeal, rejected the application judge's conclusion that Figueroa was a controlling precedent. He distinguished the funding thresholds at issue here from the 50-candidate requirement considered in Figueroa and noted that they were less onerous and prejudicial than the 50 -candidate requirement. ${ }^{83}$ Despite being a lesser evil, the Court noted that the funding thresholds "enhance the imbalance on an already tilted playing field as between larger and smaller parties and exacerbate the differences in the respective parties' ability to communicate their message." ${ }^{84}$ On this basis, Blair J. upheld the application judge's conclusion that the funding thresholds violated s. 3 of the Charter. ${ }^{85}$

The Court of Appeal rejected the application judge's justification analysis under s. 1 of the Charter. Under s. 1 of the Charter, the Court follows the well worn analytical path first

$81 \quad$ Longley (Sup. Ct. J.), supra note 3 at para. 28.

82 For a discussion of the importance of conflict of interests in democratic process cases, see Feasby, “Constitutional Questions,” supra note 2; Christopher Manfredi \& Mark Rush, “Electoral Jurisprudence in the Canadian and U.S. Supreme Courts: Evolution and Convergence” (2007) 52 McGill L.J. 457; Samuel Issacharoff \& Richard H. Pildes, "Politics as Markets: Partisan Lockups of the Democratic Process” (1988) 50 Stan. L. Rev. 643.

$83 \quad$ Supra note 3 at para. 43.

$84 \quad$ Ibid. at para. 41.

Ibid. at para. 44. 
articulated by the Supreme Court of Canada in $R . v$. Oakes. ${ }^{86}$ First, it is asked whether the impugned provision has a pressing and substantial objective. If there is a pressing and substantial objective, then the Court considers three questions: (1) whether the objective and the provision are rationally connected; (2) whether the provision minimally impairs the right in question; and (3) whether the salutary effects of the provision outweigh the deleterious effects.

Justice Blair began by identifying a pressing and substantial objective. He accepted that the objective of the thresholds was the prevention of the misuse of public funds which, in turn, undermined public confidence in the integrity of the electoral process and the associated public funding system: "Parliament is not saying it cannot afford to pay the quarterly allowances to smaller parties. It is saying that steps must be taken to ensure that political party funding is preserved for legitimate public discourse.”87 The Court went on to hold that the funding thresholds were rationally connected to the objective of preventing misuse of funds to maintain public confidence in the electoral system. ${ }^{88}$

Minimal impairment often comprises analysis of two concepts. This first is overbreadth, which involves situations where legislative provisions apply to individuals or conduct that is unnecessary to achieve the objective of the legislation. The overbreadth of the funding thresholds - the fact that small political parties that genuinely participate in the electoral process are caught — was tolerable, according to the Court of Appeal, "given Parliament's reasoned apprehension of the harm addressed." 89 The second concept involved in an analysis of minimal impairment requires consideration of alternative means of achieving the legislative objective. In the case of the misuse of funds, any alternative to a funding threshold would entail some form of audit and enforcement. ${ }^{90}$ Such a regime was rejected by the Court as undesirable because it would interfere with the internal workings of political parties and could possibly compromise the independence of the Chief Electoral Officer. ${ }^{91}$ Even if some form of audit regime could be constructed, the Court concluded that the thresholds would still be justifiable because Parliament is not restricted to the least intrusive means. ${ }^{92}$ After considering the question of minimal impairment in some depth, the Court held that "it would not be appropriate for us to interfere with [Parliament's] choice of means in these circumstances." 93 The Court concluded its proportionality analysis by weighing the salutary and deleterious effects of the funding thresholds. As is often the case, this final balancing process enumerated the positive and negative aspects of the legislation considered in previous parts of the s. 1 analysis. The Court then offered a summation of its decision: "the goal of upholding the integrity of [the electoral] regime overshadows the value of absolute equality in the treatment of all political parties in terms of access to public funding." ${ }^{94}$

[1986] 1 S.C.R. 103.

Longley (C.A.), supra note 3 at para. 49.

Ibid. at para. 54.

Ibid. at para. 78 .

Ibid. at para. 66.

Ibid. at paras. 68, 72.

Ibid. at para. 75 .

Ibid. at para. 78 .

Ibid. at para. 83 . 


\section{SUPREME COURT OF CANADA}

Longley and the other plaintiffs sought leave to appeal the Court of Appeal's decision to the Supreme Court of Canada. The test for leave to appeal to the Supreme Court is one of "public importance." 95 While only a small percentage of leave applications are granted by the Supreme Court, ${ }^{96}$ a constitutional challenge implicating the federal electoral process, such as Longley, would seem to be an appropriate case for leave. The case for leave in Longley was particularly strong because the Ontario Court of Appeal's reasons appear to be inconsistent with Figueroa in significant respects. Despite this, the Supreme Court denied the application for leave on 24 April 2008. ${ }^{97}$ A denial of leave is not ascribed any jurisprudential significance in Canada. As a result, it cannot be said whether the Supreme Court agrees with the Ontario Court of Appeal. The result is that the constitutional status of small political parties is murky. Clarity will have to wait for another case.

\section{Third Parties and SMall Political Parties: APPLES AND ORANGES?}

\section{A. CONSTITUTIONAL JUSTIFICATIONS FOR REGULATING Third Parties and Small Political Parties}

\section{THIRD PARTIES AND THE “Misuse OF FUNDS”}

The Ontario Court of Appeal in Longley found that it was a pressing and substantial objective that public funding for political parties not be misused. The Court, however, never explicitly stated what constituted "misuse" of public funding. From the examples of misuse cited by the Court, occurrences by the Natural Law Party and the Rhinoceros Party, it might be inferred that the Court was concerned only with funding for quasi-commercial cults and satirical political parties. While this might be a plausible reading of the Court of Appeal's reasons, it is not consistent with the position advocated by the Attorney General. The Attorney General was quite clearly concerned not only with the most colourful examples, but also with the more mundane possibility that third parties might morph into single issue political parties in order to qualify for public funding.

The problem of third parties is a recurring theme in the affidavits of political science experts filed by the Attorney General in Longley. Professor Ewing, for example, gave evidence that even where an equality rationale is accepted, thresholds may be justified "on the ground that they ensure that public money is made available to representative organisations, and on the ground that they help to eliminate the risk of opportunism by third parties which seek to take advantage of benefits made available to political parties."98 Professor Aucoin similarly observed that "third parties that otherwise would come into 
existence to support or oppose a particular political party in a particular election campaign might become registered political parties." 99

All of this begs the question: what exactly is wrong with a third party becoming a political party ${ }^{100}$ And how is the receipt of public funding by a third party that becomes a political party a "misuse" of public funding? To get to the bottom of this, the rationale for regulating third parties in the first place needs to be considered. One of the key justifications for limiting third party spending is to protect the integrity of political party and candidate spending limits. According to this view, third parties must not be used as a vehicle to avoid political party and candidate spending limits or to unfairly prejudice political parties and candidates who are subject to spending limits. By contrast, one of the key rationales for limiting the rights of small political parties is that there is a risk that they could be third parties in disguise. Even if this is so, it is not clear why this is a threat to the integrity of the political process. If the main threat posed by third parties used to be that they were unregulated and could undermine political party and candidate spending limits, it would seem that such a threat disappears once a third party registers as a political party and submits to the regulatory regime applicable to political parties.

\section{IS THERE A DistinCTION BETWEEN THIRD PARTIES AND SMALl POLITICAL PARTIES?}

Another question that emerges from Longley is whether any constitutional basis for drawing distinctions between third parties and small political parties remains. One implication that might be drawn from Longley is that, notwithstanding Figueroa, small political parties occupy a subordinate place in the political process that is little different from that of third parties. Professor Young testified in Longley that it "is very difficult to draw a clear line of demarcation between interest groups and political parties." ${ }^{101}$ Indeed, there is no question that third parties and small political parties share some characteristics. Often third parties and small political parties are focused on single issues. Neither stands any chance of participating in government: third parties because they do not nominate candidates, and small political parties because they do not get enough votes. As such, the functional roles of third parties and small political parties are similar. Both provide voices for opinions and issues that are not represented by the major political parties. In this way, third parties and small political parties perform an important participatory function and catalytic function for political debate. The similarities between the two raise the question of whether they should be treated the same.

Despite the similarities, there are also important differences. Small political parties are committed to the election of candidates, however rarely that actually occurs, and to participating in electoral debate. Between elections, most small political parties have a low profile which is in contrast to some third parties. Third parties often share the objective of participating in electoral debate, although their participation takes a fundamentally different

Indeed, arguably the Co-operative Commonwealth Federation (CCF), the predecessor to today's New Democratic Party (NDP), was a product of labour and other interest groups joining together to enter the electoral arena. The influence of organized labour remains strong in the NDP.

101 Young Affidavit, supra note 69 at para. 18. 
form because they are not allowed to promote candidates. Most third parties also have a broader mandate that extends beyond the election period. Third parties outside of the election period - then more properly called individuals and interest groups - have many other purposes including promoting causes, raising public awareness of issues, lobbying governments, raising money for charity, and pursuing commercial objectives.

The existence of two different regulatory categories within the political finance regime one for third parties and one for political parties - allows groups of citizens to choose the mode of participation that best fits their objectives. There is no need, as Professor Young implies, for courts to make a distinction between third parties and small political parties. Under the current regulatory regime, groups of citizens are able to define themselves as either third parties or political parties and submit to the appropriate regulations. No compelling reasons have been offered to question the choices made by groups of citizens to constitute themselves as either a third party or a small political party.

Just because there are practical reasons for making a regulatory distinction between third parties and political parties does not mean that the distinction necessarily has any constitutional significance. Indeed, I have argued previously that the third party cases implicitly assume a constitutional hierarchy that places political parties above third parties. ${ }^{102}$ One of the central reasons for limiting third parties' freedom of expression is to support the political finance system for political parties. For such a reason to be accepted, there must first be a conclusion that the interests of political parties in the context of an election are more important than the interests of third parties. Another way to put it is that the interests of citizens as candidates and voters require that political parties be elevated above third parties. The best argument for this hierarchy is that political parties are vehicles that are necessary for individuals to jointly exercise their political rights under s. 3 of the Charter. ${ }^{103}$ Moreover, while political parties are not explicitly recognized in the written parts of the Canadian constitution, political parties clearly perform a constitutional function in making responsible government possible. ${ }^{104}$ Without political parties, Parliament could not function effectively. This is consistent with the Lortie Commission's conclusion that election law should recognize the imperative objective of "strengthening political parties as primary political organizations.”105

Even if it is accepted that there is a constitutional distinction between political parties and third parties, it can always be argued that the distinction should only apply to large political

Colin Feasby, "Libman v. Quebec (A.G.) and the Administration of the Process of Democracy under the Charter: The Emerging Egalitarian Model” 44 McGill L.J. 5 at 34-36.

Perhaps the best articulation of this concept is found in an entirely different context in the concurring and partially dissenting reasons of Kennedy J. in Colorado Republican Federal Campaign Committee v. Federal Election Commission, 518 U.S. 604 (1996) at 629-30:

A political party has its own traditions and principles that transcend the interests of individual candidates and campaigns; but in the context of particular elections, candidates are necessary to make the party's message known and effective, and vice versa.

We have a constitutional tradition of political parties and their candidates engaging in joint First Amendment activity; we also have a practical identity of interests between the two entities during an election.

Canada, Royal Commission on Electoral Reform and Party Financing, Reforming Electoral Democracy: Final Report, vol. 1 (Ottawa: Communication Group, 1991) at 11-13 (Chair: Pierre Lortie) [Lortie Commission].

Ibid. at 13 . 
parties (however defined). Indeed, that was the thrust of the Attorney General's position in Figueroa, where it was argued that the 50-candidate threshold was reasonable for registration as a political party, as only large political parties are capable of aggregating public opinion and forming a government. This was rejected in Figueroa on the grounds that political parties of all sizes perform the important function of facilitating citizen participation in the electoral debate. ${ }^{106}$ Another argument against drawing lines between small political parties and large political parties is that small political parties sometimes become large political parties. Canadian history is littered with examples of small political parties that grew into significant Parliamentary presences: the Progressive Party, the CCF, the NDP, the Social Credit Party, the Bloc Quebecois, and the Reform Party. The Charter should not be interpreted to support, let alone mandate, measures that make it more difficult for small political parties to gain the traction required to become large political parties.

\section{B. Are Third Parties a Real Threat to Political Party Financing?}

The evidence of Professors Ewing and Aucoin concerning the threat posed by third parties registering as political parties is expressed in terms of risk or possibility. Professor Young, by contrast, asserted in her evidence that the issue is real and not hypothetical at all. ${ }^{107}$ She identified one example of a third party acting in concert with a small political party: Environment Voters, the president of which was registered as a third party in the 2000 federal general election, shares an address and personnel with a currently registered party named Animal Alliance Environment Voters Party of Canada. ${ }^{108}$ The question is whether this lone example shows that the risk of third parties masquerading as political parties is "not merely hypothetical” or whether it suggests exactly the opposite. ${ }^{109}$ Whether or not the third party threat is real can also be considered in light of: (1) the differences between the third party and political party regulatory frameworks; and (2) the experience over the last few years as the controls on third parties were adopted and the treatment of small political parties became more generous.

Third parties and political parties are both regulated by the CEA. There are, however, important distinctions between the regulations that apply to each. Third party regulation is limited to the statutorily defined election period that precedes the election day. ${ }^{110}$ During the election period, third parties are subject to spending limits and some reporting and disclosure obligations. As explained in Part II of this article, third party spending limits are meagre compared to political party spending limits. Outside the election period, the activities of third parties are unfettered. Third parties may raise and spend unlimited amounts of money outside an election period without any scrutiny of its contributor list.

The regulatory regime that applies to political parties operates year-round, not just during an election period. Political parties receive quarterly allowances, partial reimbursement of election expenditures, and may issue tax receipts, but are limited in their fundraising by contribution limits on individuals and a prohibition on contributions by corporations. 
Moreover, political parties have to file audited annual returns with Elections Canada. ${ }^{111}$ During an election period political parties enjoy much more generous spending limits, but are also subject to more stringent reporting requirements. Perhaps most significantly, political parties must run candidates for election. While a political party only requires a single candidate to meet the registration requirement, spending limits are tied to the number of electoral districts in which the political party nominates candidates. ${ }^{112}$ In other words, unless a political party runs candidates in lots of electoral districts, it has a small spending limit.

The differences between the third party and political party regulatory regimes make it unattractive for a third party to become a political party unless it shares the main objective of a political party: namely, to elect candidates. The cost of compliance with the regulations applicable to political parties, the enhanced rules regarding disclosure of contributors, and limits on contributions make it unattractive for many third parties to become political parties. Perhaps most importantly, the risk of a third party creating a captive political party (as was arguably the case in Professor Young's example) is largely mitigated by the limits on contributions to political parties and the rules against collusion between third parties and political parties. A corporate third party with a captive political party would be precluded from contributing to the political party, and individuals and unincorporated third parties would be limited to the individual contribution amount.

While as a matter of logic it appears that there is little incentive for a third party to become a political party unless it genuinely seeks to elect candidates, it is useful to consider the impact of recent changes in the third party and political party regulatory framework. Table 2, below, shows what the annual allowances of small political parties would have been from 2 April 2008 to 31 March 2009 if there were no funding thresholds. The meagre amounts that would have been received by small political parties indicate that misuse of public funds is not commercial in nature, as no rational actor would assume the financial and regulatory burden of registering as a political party to obtain such modest sums. ${ }^{113}$ Moreover, none of the parties that would have received allowances are commercial entities, and most are not frivolous in the sense that their mandate is to mock the political process, or are otherwise insincere in their participation in the political process. ${ }^{114}$ Some, such as the CCP, have a long tradition of participating in Canadian public life.

Two changes in the CEA test the argument that there is a risk that third parties will take advantage of the regulatory regime applicable to political parties to evade third party restrictions and to avail themselves of public funding for political parties. The hypothesis that third parties can, or will, morph into political parties can be tested by looking at the experience that followed the introduction of the third party regulatory regime in 2000, and the liberalizing of funding for small political parties brought about by Figueroa in 2003. The

$111 \quad$ Ibid., ss. $424-27$.

112 Ibid., s. 422 . The formula is $\$ 0.70$ multiplied by the inflation factor multiplied by the number of registered voters in electoral districts where the political party is running candidates.

113 It must be acknowledged that greater sums may be obtained under the election expense reimbursement regime. However, even there it is questionable whether a rational actor would constitute itself as a political party. Again, it is necessary to run lots of candidates to obtain a high spending limit, and only 50 percent of funds spent are reimbursed. It is difficult to envision a commercial scheme where this makes any sense.

The Work Less Party and Neorhino.ca Party appear to be satirical in nature. 
third party regulations adopted in 2000 made it less attractive to be a third party without providing any corresponding benefits. Conversely, Figueroa and subsequent amendments to the CEA made registration as a political party less onerous and enabled small political parties to raise money more effectively by issuing tax receipts to donors. Together, these changes appear to create an incentive for third parties to transform into political parties or to create an allied political party for election period advocacy.

TABLE 2

Notional Small Party Annual Allowances BASED ON 2008 ELECTION RESULTS ${ }^{115}$

\begin{tabular}{|l|l|l|l|l|}
\hline Party & $\mathbf{2 0 0 8}$ Vote Total & $\begin{array}{l}\text { Per Vote } \\
\text { Allowance }\end{array}$ & $\begin{array}{l}\text { Inflation } \\
\text { Factor }\end{array}$ & $\begin{array}{l}\text { Annual } \\
\text { Allowance }\end{array}$ \\
\hline $\begin{array}{l}\text { Animal Alliance Environment } \\
\text { Voters Party of Canada }\end{array}$ & 527 & $\$ 1.75$ & 1.116 & $\$ 1,029.23$ \\
\hline Canadian Action Party & 3,455 & $\$ 1.75$ & 1.116 & $\$ 6,747.62$ \\
\hline Christian Heritage Party & 26,475 & $\$ 1.75$ & 1.116 & $\$ 51,705.68$ \\
\hline Communist Party of Canada & 3,572 & $\$ 1.75$ & 1.116 & $\$ 6,976.12$ \\
\hline $\begin{array}{l}\text { First Peoples National Party of } \\
\text { Canada }\end{array}$ & 1,611 & $\$ 1.75$ & 1.116 & $\$ 3,146.28$ \\
\hline Libertarian Party of Canada & 7,300 & $\$ 1.75$ & 1.116 & $\$ 14,256.90$ \\
\hline Marijuana Party & 2,298 & $\$ 1.75$ & 1.116 & $\$ 4,487.99$ \\
\hline Marxist-Leninist Party of Canada & 8,565 & $\$ 1.75$ & 1.116 & $\$ 16,727.45$ \\
\hline $\begin{array}{l}\text { Newfoundland and Labrador First } \\
\text { Party }\end{array}$ & 1,713 & $\$ 1.75$ & 1.116 & $\$ 3,345.49$ \\
\hline $\begin{array}{l}\text { People's Political Power Party of } \\
\text { Canada }\end{array}$ & 186 & $\$ 1.75$ & 1.116 & $\$ 830.03$ \\
\hline Progressive Canadian Party & 5,860 & $\$ 1.75$ & 1.116 & $\$ 363.26$ \\
\hline Western Block Party & 195 & $\$ 1.75$ & 1.116 & $\$ 16,444.58$ \\
\hline Work Less Party & 2,122 & 1.116 & $\$ 380.84$ \\
\hline Neorhino.ca Party & $\$ 64,304$ & & & \\
\hline TOTAL & & $\$ 1.75$ & \\
\hline
\end{tabular}

Given the incentive created by the changes, one would expect to see the number of political parties rise. However, the number of registered political parties has not changed 
significantly over the last 16 years. The numbers of registered political parties or political parties that tried to register, as shown in Table 3, below, range from ten to 24 over the period for which data is available with no discernable trend. The number of registered parties in 2008 is less than attempted to register in 1993. In 1993, a total of 24 political parties were registered, deregistered for failing to run enough candidates, or were refused registration. Similarly, the low number of registered political parties in the period, ten, was a result of seven political parties either being deregistered or being refused registration as a result of not meeting the requirements for registration in existence prior to Figueroa.

TABLE 3

Number of Registered Political PARTies ${ }^{116}$

\begin{tabular}{|c|c|c|c|c|}
\hline Year & Registered & $\begin{array}{l}\text { Deregistered or } \\
\text { Suspended }\end{array}$ & $\begin{array}{l}\text { Registration } \\
\text { Denied }\end{array}$ & Total \\
\hline 2008 & 19 & & & 19 \\
\hline 2007 & 15 & & & 15 \\
\hline 2006 & 15 & & & 15 \\
\hline 2005 & 12 & & & 12 \\
\hline 2004 & 12 & 1 & 3 & 16 \\
\hline 2003 & 11 & & & 11 \\
\hline 2002 & 11 & & & 11 \\
\hline 2001 & 11 & & & 11 \\
\hline 2000 & 11 & 1 & & 12 \\
\hline 1999 & 10 & & & 10 \\
\hline 1998 & 10 & & & 10 \\
\hline 1997 & 10 & 5 & 2 & 17 \\
\hline 1996 & 14 & & & 14 \\
\hline 1995 & 14 & & & 14 \\
\hline 1994 & 14 & & & 14 \\
\hline 1993 & 14 & 4 & 6 & 24 \\
\hline
\end{tabular}




\section{Conclusion}

The Supreme Court of Canada did the Canadian political system a disservice by not granting leave to appeal in Longley. The decision in Longley calls into question the Supreme Court's decision in Figueroa and appears to be inconsistent with a nearly contemporaneous decision of the Ontario Superior Court of Justice; only days before the Court of Appeal's decision in Longley, Perell J. issued a decision in DeJong. ${ }^{117}$ The issue in DeJong was the constitutionality of a requirement in Ontario's Election Act ${ }^{118}$ for candidates to provide deposits refundable only if the candidate obtains 10 percent of the vote. The Court accepted the Ontario Attorney General's submission that the objective of the 10 percent threshold for the return of funds was to reduce the number of frivolous candidates. However, the Court held that any benefit of the threshold was "overcome by the deleterious effects of diminishing the capacity of [small] political parties to present their ideas and opinions."119 While there is a practical difference between return of a candidate's own funds and a grant of public funds, there is no difference in principle, as in both cases thresholds exacerbate preexisting disparities between small and large political parties and their respective candidates. After Longley, the Supreme Court's clear direction to treat small political parties as equal to major political parties in Figueroa is anything but clear. This lack of clarity will likely result in more, not less, litigation, which will force the Supreme Court to revisit the issues in Figueroa. 